\title{
Estimasi Stok Penerimaan Bahan Bakar Minyak Menggunakan Metode Fuzzy Tsukamoto
}

\author{
Fuel Stock Estimation Using Fuzzy Tsukamoto Method
}

\author{
Novianti Puspitasari ${ }^{*}$, Andi Tejawati ${ }^{2}$, Friendy Prakoso ${ }^{3}$ \\ 1,2,3)Jurusan Teknolgi Informasi dan Komunikasi, Fakultas Ilmu Komputer \& Teknologi Informasi \\ Universitas Mulawarman \\ Jl. Panajam Kampus Gn. Kelua, Samarinda, Kalimantan Timur. Telp (0541)753133 \\ *email : novia.ftik.unmul@gmail.com
}

\begin{abstract}
DOI;
10.30595/jrst.v3i1.3112

Bahan bakar merupakan salah satu kebutuhan yang saat ini

Histori Artikel:

Diajukan:

$04 / 08 / 2018$

Direvisi:

$10 / 01 / 2019$

Diterima:

$23 / 01 / 2019$

ABSTRAK

tidak bisa dilepaskan dari masyarakat. Bahan bakar cair terutama bensin atau premium, pertalite, pertamax, dan solar merupakan bahan bakar yang digunakan pada alat transportasi. Semakin banyak alat transportasi yang dimiliki masyarakat dapat memungkinkan tidak tersedianya stok bahan bakar di salah satu SPBU (Stasiun Pengisian Bahan Bakar Umum) tertentu. Dengan tidak tersedianya stok persediaan bahan bakar di SPBU, hal ini dapat menimbulkan beberapa masalah, seperti antrian yang panjang pada salah satu SPBU, serta kurangnya kebutuhan bahan bakar pada masyarakat. Salah satu metode untuk memecahkan masalah tersebut adalah menggunakan metode Fuzzy Tsukamoto. Fuzzy Tsukamoto merupakan salah satu metode yang termasuk ke dalam sistem inferensi fuzzy. Metode ini dapat menentukan jumlah produksi, sehingga jumlah produksi sebuah barang dapat diprediksi. Hasil penelitian menunjukkan bahwa metode Tsukamoto mampu memprediksi jumlah penerimaan stok bahan bakar yang seharusnya diterima oleh SPBU pada periode berikutnya. Dimana, hasil pengujian ketepatan prediksi diukur dengan menggunakan metode MAPE (Mean Absolute Percentage Error) dengan nilai persentase error yang didapatkan adalah sebesar $16 \%$, sehingga kinerja sistem dalam memprediksi stok bahan bakar dapat dikatakan bagus.
\end{abstract}

Kata kunci: fuzzy Tsukamoto, MAPE, stok, bahan bakar, sistem inferensi fuzzy

\begin{abstract}
Fuel is one of the needs that cannot be released from the community. Liquid fuels, especially gasoline or Premium, Pertalite, Pertamax, and diesel are fuels used in transportation. The increasing number of means of transportation owned by the community can allow the unavailability of fuel stock in one particular gas station (General Fuel Filling Station). The unavailability of fuel stockpiles at gas stations, this can lead to several problems, such as long queues at one gas station, as well as a lack of fuel needs for the community. One method to solve this problem is using the Fuzzy Tsukamoto method. Fuzzy Tsukamoto is one of the methods included in the fuzzy inference system. This method can determine the amount of production so that the amount of production of an item can be predicted. The results showed that Tsukamoto's method was able to predict the amount of receipt of fuel stock that should be received by gas stations in the next period. Where, the results of the prediction accuracy are measured using the MAPE (Mean Absolute Percentage Error) method with the percentage error obtained is $16 \%$, so the system performance in predicting fuel stock can be said to be good.
\end{abstract}

Keywords: fuzzy Tsukamoto, MAPE, stock, fuel, fuzzy inference system 


\section{PENDAHULUAN}

Saat ini bahan bakar cair (disebut bahan bakar minyak) merupakan salah satu kebutuhan yang tidak bisa dilepaskan dari masyarakat. Dimana, bahan bakar minyak (BBM) merupakan salah satu faktor yang penting pada mesin kendaraan. Semakin meningkatnya jumlah kendaraan yang dimiliki oleh masyarakat maka semakin tinggi pula konsumsi BBM di masyarakat.

Konsumsi BBM yang semakin meningkat dari tahun ke tahun memungkinkan ketiadaan stok persediaan BBM di salah satu SPBU (Stasiun Pengisian Bahan Bakar Umum) tertentu. Dengan kekosongan stok persediaan bahan bakar di SPBU, maka hal ini dapat menimbulkan berbagai masalah. Salah satunya adalah antrian panjang yang terjadi di SPBU, sehingga menyebabkan mobilitas masyarakat terganggu.

Salah satu solusi yang dapat digunakan untuk mengurangi kehabisan stok BBM di SPBU adalah dengan cara mengetahui estimasi stok yang dibutuhkan untuk periode selanjutnya. Penelitian tentang prediksi bahan bakar minyak telah dilakukan diantaranya penelitian untuk mengetahui jumlah pembelian dan penjualan bahan bakar industri di sebuah perusahaan agen bahan bakar menggunakan metode Backpropagation Neural Network (Sari, 2015). Selanjutnya, penelitian tentang prediksi kebutuhan bahan bakar jenis premium disebuah stasiun bahan bakar menggunakan metode Hibrida Arima dan Neural Network. Hasil penelitian menunjukkan bahwa model persediaan yang optimal terjadi ketika jumlah safety stock adalah 87 Kl. Penelitian ini juga membuktikan bahwa metode hibrida dapat memberikan hasil prediksi yang lebih baik dibandingkan dengan metode tunggal dengan nilai RMSE yang kecil (Kusumaningrum, Suhartono, \& Haryono, 2012)

Metode lainnya yang dapat digunakan untuk memprediksi atau meramalkan stok bahan bakar adalah Logika Fuzzy. Logika fuzzy merupakan salah satu metode pembentuk soft computing yang berbeda dengan conventional computing. Logika fuzzy memungkinkan toleransi terhadap input, proses dan output yang bersifat tidak akurat (imprecision), tidak pasti (uncertainty) dan setengah benar (partial truth). Di dalam konsep logika Fuzzy terdapat metode yang dapat menentukan jumlah produksi yang disebut dengan Sistem Inferensi Fuzzy. Ada tiga metode dalam Sistem Inferensi Fuzzy yang dapat digunakan untuk menentukan jumlah produksi, yaitu metode Tsukamoto, metode Mamdani, dan metode Sugeno (Setiadji, 2009).

Metode Tsukamoto telah banyak diterapkan untuk peramalan, pengambilan keputusan dan perencanaan diantaranya adalah memprediksi kuantitas permintaan bahan baku dengan parameter penjualan, permintaan dan masa kadaluarsa (Huda, 2018). Selanjutnya, penerapan metode Tsukamoto dalam menentukan volume impor bawang merah (Widayani, Kusrini, \& Al Fatta, 2015), menentukan pemasok bahan baku pada suatu perusahaan (Santika \& Mahmudy, 2015), memprediksi tingkat kerawanan kebakaran dibeberapa kecamatan di kota Kudus (Ardianto, Haryanto, \& Mulyanto, 2018), memprediksi ketersediaan kayu jati berdasarkan variabel yang mempengaruhinya (Hayadi, 2015) dan memprediksi jumlah produksi roti dengan nilai error yang didapatkan sebesar 1\% (Minarni \& Aldyanto, 2016) dan lain sebagainya (Caraka, Haryanto, Kusumaningrum, \& Astuti, 2015; Kusuma, Puspitasari, \& Gustiyoto, 2018; Puryanto, 2016).

Penelitian ini menerapkan Fuzzy Inference System dengan metode Tsukamoto. Metode ini nantinya dimasukkan ke dalam sebuah sistem yang dapat mempermudah pihak SPBU untuk memprediksi stok bahan bakar pada periode berikutnya. Metode ini dipilih karena sifatnya yang fleksibel, dan memiliki toleransi pada data yang ada. Kelebihan dari metode ini yaitu lebih cepat dalam melakukan komputasi, lebih intuitif, diterima oleh banyak pihak, serta lebih cocok untuk masukan yang diterima dari manusia bukan oleh mesin (Caraka et al., 2015). Lebih lanjut, penelitian ini dapat membantu pihak SPBU dalam memberikan informasi prediksi penerimaan stok BBM, agar persediaan BBM tidak mengalami kekurangan.

\section{METODE PENELITIAN}

Pada bagian ini akan dijelaskan secara singkat Logika Fuzzy, metode Fuzzy Tsukamoto, dan analisis uji validitas terhadap peramalan yang dilakukan.

\section{A. Logika Fuzzy}

Logika fuzzy merupakan logika yang berhadapan dengan konsep kebenaran 
sebagian, dimana logika klasik menyatakan bahwa nilai kebenaran dapat diekspresikan dalam istilah binary (0 atau 1). Sedangkan logika fuzzy memungkinkan nilai keanggotaan antara 0 dan 1 . Dengan menggunakan metode tersebut diharapkan dapat membantu perusahaan dalam menentukan jumlah produksi (Kusuma et al., 2018). Pada teorinya, logika fuzzy bukanlah merupakan pengganti dari teori probabilitas namun merupakan cara lain untuk menyelesaikan masalah ketidakpastian. Komponen utama yang sangat berpengaruh adalah fungsi keanggotaan. Fungsi keanggotaan menyatakan derajat keanggotaan pada suatu himpunan. Fungsi keanggotaan adalah suatu kurva yang menunjukkan titik-titik input data kedalam nilai keanggotaan yang berada dalam interval 0 sampai 1. Fungsi keanggotaan dinyatakan dengan $\mu$ A. Salah satu cara yang dapat digunakan untuk mendapatkan nilai keanggotaan adalah dengan melalui pendekatan fungsi (Kusumadewi \& Purnomo, 2004).

\section{B. Metode Fuzzy Tsukamoto}

Sistem kendali logika fuzzy disebut juga Sistem Inferensi Fuzzy (Fuzzy Inference System/FIS) adalah sistem yang dibuat untuk melakukan penalaran. Konsep dari sistem ini meniru manusia yang melakukan penalaran dengan nalurinya. FIS terbagi menjadi beberapa jenis, yaitu Tsukamoto, Mamdani, dan Sugeno. Metode Tsukamoto adalah perluasan dari penalaran monoton. Pada metode Tsukamoto, setiap konsekuen pada aturan yang berbentuk IF-THEN harus direpresentasikan dengan suatu himpunan fuzzy dengan fungsi keanggotaan yang monoton. Sebagai hasilnya, output hasil inferensi dari tiap-tiap aturan diberikan secara tegas (crisp) berdasarkan $\alpha$-predikat (fire strength). Hasil akhirnya diperoleh dengan menggunakan rata-rata terbobot (Kusumadewi \& Purnomo, 2004). Bentuk model Fuzzy Tsukamoto adalah sebagai berikut.

IF (X IS A) and (Y IS B) then (Z IS C)

Dimana A, B, dan C adalah himpunan Fuzzy. Dalam inferensinya, metode Tsukamoto menggunakan tahapan sebagai berikut:

1) Fuzzifikasi yaitu proses memetakan crisp input ke dalam himpunan fuzzy.
Hasil dari proses ini berupa fuzzy input dalam bentuk rule fuzzy.

2) Pembentukan Rule (aturan) dalam bentuk IF ... THEN.

3) Mesin inferensi, proses input Fuzzy menjadi output Fuzzy dengan mengikuti aturan yang telah ditetapkan, hasil tersebut biasa disebut dengan $\alpha$ predikat $(\alpha 1, \alpha 2, \alpha 3 \ldots . \alpha \mathrm{n})$.

4) Defuzzifikasi, yaitu proses mengubah fuzzy output menjadi crisp value. Metode defuzzifikasi menggunakan metode rata - rata (Average) seperti yang terlihat pada persamaan 1 .

$$
z=\frac{\sum a_{i} z_{i}}{\sum a_{i}}
$$

Keterangan:

$\mathrm{Z}$ = variabel output

$a_{i}=$ nilai $\alpha$ predikat

$Z_{i}=$ nilai variabel output masing - masing aturan implikasi

Selanjutnya, flowchart dari metode Fuzzy Tsukamoto yang dapat dilihat pada Gambar 1.

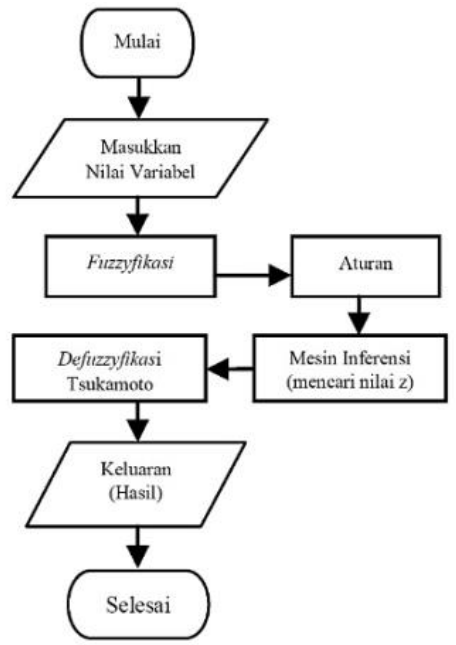

Gambar 1. Flowchart fuzzy Tsukamoto

\section{Datasets}

Di dalam penelitian ini, datasets pengujian berupa dataset BBM jenis premium dari bulan Januari 2016 - Februari 2017 yang terdapat di salah satu SPBU kota Samarinda. Data BBM jenis premium ditampilkan pada Tabel 1. 
Tabel 1. Data BBM Premium

\begin{tabular}{cccc}
\hline $\begin{array}{c}\text { Bulan/Tah } \\
\text { un }\end{array}$ & $\begin{array}{c}\text { Stok } \\
\text { Awal } \\
\text { (Liter) }\end{array}$ & $\begin{array}{c}\text { Penjualan } \\
\text { (Liter) }\end{array}$ & $\begin{array}{c}\text { Penerimaan } \\
\text { (Liter) }\end{array}$ \\
\hline Jan - 2016 & 41.955 & 489.501 & 496.000 \\
Feb - 2016 & 36.215 & 468.513 & 456.000 \\
Mar - 2016 & 20.921 & 481.302 & 480.000 \\
Apr - 2016 & 18.715 & 408.215 & 408.000 \\
Mei - 2016 & 16.881 & 459.708 & 464.000 \\
Jun - 2016 & 20.130 & 510.213 & 512.000 \\
Jul - 2016 & 19.895 & 448.760 & 440.000 \\
Agt - 2016 & 8.141 & 448.086 & 464.000 \\
Sept - 2016 & 21.144 & 410.060 & 400.000 \\
Okt - 2016 & 9.896 & 400.032 & 408.000 \\
Nov - 2016 & 15.957 & 403.128 & 392.000 \\
Des - 2016 & 3.274 & 277.339 & 288.000 \\
Jan - 2017 & 12.514 & 373.435 & 376.000 \\
Feb - 2017 & 13.181 & 289.422 & 280.000 \\
\hline
\end{tabular}

Dari Tabel 1 dapat diperoleh informasi bahwa terdapat tiga variabel yang akan digunakan dalam variabel fuzzy yaitu penjualan, stok awal (persediaan) dan penerimaan dalam satuan liter. Adapun varibel penjualan menjelaskan mengenai jumlah penjualan BBM jenis premium yang dijual oleh SPBU. Sementara, varibel stok menjelaskan mengenai jumlah persediaan BBM premium yang tersisa di SPBU. Sedangkan, variabel penerimaan menjelaskan mengenai jumlah penerimaan BBM yang diterima oleh SPBU dari Pertamina.

\section{Pendefinisan Variabel Fuzzy}

Variabel yang telah didapatkan pada dataset kemudian didefinisikan ke dalam variabel fuzzy yang dipetakan menjadi dua variabel input yaitu variabel persediaan dan variabel penjualan. Dan, variabel output yaitu variabel penerimaan. Setelah menentukan variabel input dan output, selanjutnya mencari nilai keanggotaan maksimum dan minimum dari masing-masing variabel dengan menggunakan fungsi keanggotaan himpunan fuzzy dari tiap variabel seperti berikut.

1. Variabel penjualan terdiri dari 2 himpunan Fuzzy yaitu: Turun dan Naik.

Sementara, fungsi keanggotaan himpunan Fuzzy Turun dari variabel penjualan ditunjukkan oleh persamaan 2.

$$
\mu P n j T \operatorname{urun}[x]=\left\{\begin{array}{cl}
1 & , x \leq x_{\min } \\
\frac{x_{\max }-x}{x_{\max }-x_{\min }}, & x_{\min } \leq x_{\max } \\
0 & , x \geq x_{\max }
\end{array}\right.
$$

Fungsi keanggotaan himpunan Fuzzy Naik dari variabel penjualan ditunjukkan oleh persamaan 3 .

$\mu$ PnjNaik $[x]=\left\{\begin{array}{cl}0 & , x \leq x_{\min } \\ \frac{x-x_{\min }}{x_{\max }-x_{\min }}, & x_{\min } \leq x_{\max } \\ 1 & , x \geq x_{\max }\end{array}\right.$ (3)

Keterangan:

$\mu$ PenjTurun : rata - rata Penjualan

Turun

$\mu$ PenjNaik : rata - rata Penjualan Naik

$\mathrm{x}$ : Variabel penjualan

Fungsi keanggotaan himpunan Fuzzy Turun dan Naik dari variabel penjualan dapat direpresentasikan seperti Gambar 2 .

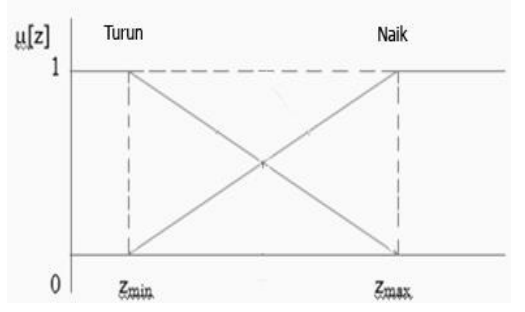

Gambar 2. Fungsi keanggotaan fuzzy variabel penjualan

2. Variabel persediaan terdiri dari 2 himpunan Fuzzy, yaitu Sedikit dan Banyak.

Sementara, fungsi keanggotaan himpunan Fuzzy Sedikit dari variabel persediaan ditunjukkan oleh persamaan 4 .

$\mu$ PsdSedikit $[y]=\left\{\begin{array}{cl}1 & , y \leq y_{\min } \\ \frac{y_{\max }-y}{y_{\max }-y_{\min }}, & y_{\min } \leq y_{\max } \\ 0 & , y \geq y_{\max }\end{array}\right.$

Fungsi keanggotaan himpunan Fuzzy Banyak dari variabel persediaan ditunjukkan oleh persamaan 5 .

$\mu$ PsdBanyak $[y]=$

$\left\{\begin{array}{cl}0 & , y \leq y_{\min } \\ \frac{y-y_{\min }}{y_{\max }-y_{\min }}, & y_{\min } \leq y_{\max } \\ 1 & , y \geq y_{\max }\end{array}\right.$

Keterangan:

$\mu$ PsdSedikit : rata - rata Persediaan

Sedikit

$\mu$ PsdBanyak : rata - rata Persediaan

Banyak

$\mathrm{y}$ : Variabel persediaan

Fungsi keanggotaan himpunan Fuzzy Sedikit dan Banyak dari variabel persediaan dapat direpresentasikan seperti Gambar 3. 


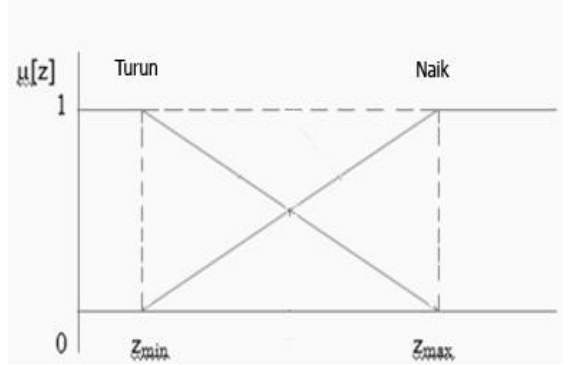

Gambar 3. Fungsi keanggotaan fuzzy variabel persediaan

3. Variabel Penerimaan terdiri dari 2 himpunan Fuzzy, yaitu Berkurang dan Bertambah.

Sementara, fungsi keanggotaan himpunan Fuzzy Berkurang dari variabel penerimaan ditunjukkan oleh persamaan 6.

$\mu$ PnrBerkurang $[z]=$

$\left\{\begin{array}{cl}1 & , z \leq z_{\min } \\ \frac{z_{\max }-z}{z_{\max }-z_{\min }}, & z_{\min } \leq z_{\max } \\ 0 & , z \geq z_{\max }\end{array}\right.$

Fungsi keanggotaan himpunan Fuzzy Bertambah dari variabel penerimaan ditunjukkan oleh persamaan 7 .

$\mu$ PnrBertambah $[z]=$

$\left\{\begin{array}{cl}0 & , z \leq z_{\min } \\ \frac{z-z_{\min }}{z_{\max }-z_{\min }}, & z_{\min } \leq z_{\max } \\ 1 & , z \geq z_{\max }\end{array}\right.$

Keterangan:

$\mu$ PnrBerkurang : rata - rata

Penerimaan Berkurang

$\mu$ PnrBertambah : rata - rata

Penerimaan Bertambah

$\mathrm{z}$ : Variabel penerimaan

Fungsi keanggotaan himpunan Fuzzy

Bertambah dan Berkurang dari variabel penerimaan dapat direpresentasikan seperti Gambar 4 .

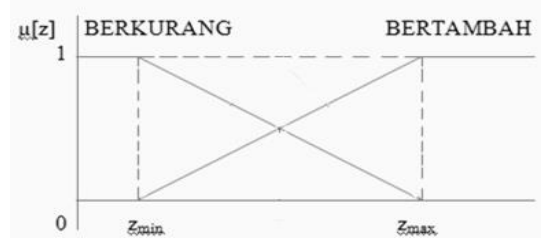

Gambar 4. Fungsi keanggotaan fuzzy variabel penerimaan.

\section{E. Mesin Inferensi}

Di dalam mesin inferensi terdapat proses untuk mengubah masukkan fuzzy menjadi keluaran fuzzy dengan cara mengikuti aturan IF-THEN yang telah ditetapkan pada basis pengetahuan fuzzy. Berdasarkan variabel fuzzy yang terbentuk, terdapat empat himpunan Fuzzy yaitu Penjualan Turun, Penjualan Naik, Persediaan Banyak, Persediaan Sedikit, Penerimaan Bertambah, dan Penerimaan Berkurang. Dengan mengkombinasikan himpunan-himpunan tersebut, maka diperoleh empat aturan Fuzzy sebagai berikut:

[R1] IF Penjualan Turun AND Persediaan Banyak THEN Penerimaan Berkurang.

Nilai keanggotaan untuk aturan Fuzzy [R1] yang dinotasikan dengan $\alpha 1$ diperoleh dengan formula sebagai berikut.

$\alpha 1=\mu$ PenjTurun $\cap \mu$ PersdBanyak

$=\operatorname{Min}(\mu$ PenjTurun $[\mathrm{x}], \mu$ PersdBanyak $[\mathrm{y}])$

Keterangan :

$\mu$ PenjTurun : rata - rata penjualan Turun $\mu$ PersdBanyak : rata - rata Persediaan Banyak.

Menurut fungsi keanggotaan himpunan Penerimaan berkurang pada persamaan (6) maka diperoleh persamaan (9)

$\frac{z_{\max }-z_{1}}{z_{\max }-z_{\min }}=\alpha 1$

Sehingga dari persamaan (9), diperoleh persamaan (10) untuk mencari nilai z1.

$z 1=z_{\text {max }}-a 1\left(z_{\max }-z_{\text {min }}\right)$

Dimana, Z1 adalah nilai z untuk aturan [R1].

[R2] IF Penjualan Turun AND Persediaan Sedikit THEN Penerimaan Berkurang.

Nilai keanggotaan untuk aturan Fuzzy [R2] yang dinotasikan dengan $\alpha 2$ diperoleh dengan formula sebagai berikut.

$\alpha 2=\mu$ PenjTurun $\cap \mu$ PersdSedikit

$=\operatorname{Min}(\mu$ PenjTurun $[\mathrm{x}], \mu$ PersdSedikit $[\mathrm{y}]) . . . .$.

Keterangan :

$\mu$ PenjTurun : rata - rata penjualan Turun $\mu$ PersdSedikit : rata - rata Persediaan Sedikit.

Menurut fungsi keanggotaan himpunan Penerimaan berkurang pada persamaan (6) maka diperoleh persamaan (13)

$\frac{z_{\max }-z_{2}}{z_{\max }-z_{\min }}=\alpha 2$

Sehingga dari persamaan (13), diperoleh persamaan (14) untuk mencari nilai z2.

$z 2=z_{\text {max }}-a 2\left(z_{\max }-z_{\text {min }}\right)$

Dimana, Z2 adalah nilai z untuk aturan [R2]. 
[R3] IF Penjualan Naik AND Persediaan Banyak THEN Penerimaan Bertambah.

Nilai keanggotaan untuk aturan Fuzzy [R3] yang dinotasikan dengan $\alpha 3$ diperoleh dengan formula sebagai berikut.

$$
\begin{aligned}
\alpha 3 & =\mu \text { PenjNaik } \cap \mu \text { PersdBanyak } \\
& =\text { Min }(\mu \text { PenjNaik }[\mathrm{x}], \mu \text { PersdBanyak }[\mathrm{y}]) \ldots
\end{aligned}
$$

Keterangan :

$\mu$ PenjNaik : rata - rata penjualan Naik $\mu$ PersdBanyak : rata - rata Persediaan Banyak.

Menurut fungsi keanggotaan himpunan Penerimaan Bertambah pada persamaan (7) maka diperoleh persamaan (16)

$\frac{z_{3}-z_{\min }}{z_{\max }-z_{\min }}=\alpha 3$

Sehingga dari persamaan (16), diperoleh persamaan (17) untuk mencari nilai z3.

$z 3=a 3\left(z_{\max }-z_{\text {min }}\right)+z_{\text {min }}$

Dimana, Z3 adalah nilai z untuk aturan [R3].

[R4] IF Penjualan Naik AND Persediaan Sedikit THEN Penerimaan Bertambah.

Nilai keanggotaan untuk aturan Fuzzy [R4] yang dinotasikan dengan $\alpha 4$ diperoleh dengan formula sebagai berikut.

$$
\begin{aligned}
\alpha 4= & \mu \text { PenjNaik } \cap \mu \text { PersdSedikit } \\
& =\operatorname{Min}(\mu \text { PenjNaik }[\mathrm{x}], \mu \text { PersdSedikit }[\mathrm{y}])
\end{aligned}
$$

Keterangan :

$\mu$ PenjNaik : rata - rata penjualan Naik $\mu$ PersdBanyak : rata - rata Persediaan Sedikit.

Menurut fungsi keanggotaan himpunan Penerimaan Bertambah pada persamaan (7) maka diperoleh persamaan (19)

$\frac{z_{4}-z_{\min }}{z_{\max }-z_{\min }}=\alpha 4$

Sehingga dari persamaan (19), diperoleh persamaan (20) untuk mencari nilai z4.

$z 4=a 4\left(z_{\max }-z_{\text {min }}\right)+z_{\text {min }}$

Dimana, Z4 adalah nilai $\mathrm{z}$ untuk aturan [R4].

\section{F. Defuzzifikasi}

Pada Metode Tsukamoto, untuk menentukan output crips, digunakan defuzzifikasi rata - rata terpusat seperti yang ditunjukkan pada persamaan (21).

$$
z=\frac{a 1 * z 1+a 2 * z 2+a 3 * z 3+a 4 * z 4}{a 1+a 2+a 3+a 4}
$$

Keterangan:

$\mathrm{Z}$ : hasil peramalan

$\alpha 1$ : Predikat 1

$\alpha 2$ : Predikat 2

$\alpha 3$ : Predikat 3

$\alpha 4$ : Predikat 4

$\mathrm{z} 1$ : hasil peramalan untuk predikat 1

$\mathrm{z} 2$ : hasil peramalan untuk predikat 2

z3 : hasil peramalan untuk predikat 3

$\mathrm{z} 4$ : hasil peramalan untuk predikat 4

\section{G. Analisis Uji Validitas Peramalan}

Di dalam metode peramalan, hasil peramalan yang dilakukan tidak selamanya selalu bernilai tepat. Hal ini dikarenakan sifat data yang ada belum tentu sesuai dengan metode peramalan yang digunakan. Oleh karena itu, perlu dilakukan uji validitas terhadap hasil peramalan sehingga dapat diketahui sesuai atau tidaknya metode peramalan yang digunakan. Dimana, untuk memilih dan menentukan metode peramalan yang sesuai dapat dilakukan dengan cara menentukan batas toleransi peramalan atas penyimpangan (error) yang terjadi. Mean Absolute Percentage Error (MAPE) merupakan metode evaluasi peramalan dengan cara membandingkan hasil prakiraan (peramalan) dengan kenyataan yang terjadi. MAPE dihitung dengan menggunakan kesalahan absolut pada tiap periode dibagi dengan nilai observasi yang nyata untuk periode itu. Selanjutnya, merata-rata kesalahan persentase absolut tersebut. MAPE mengindikasi seberapa besar kesalahan dalam meramal yang dibandingkan dengan nilai nyata (Sinaga \& Irawati, 2018). Berikut adalah formula untuk menghitung MAPE yang ditunjukkan oleh persamaan 22 .

$$
M A P E=\frac{\sum \frac{\left|x_{i}-F_{i}\right|}{x_{i}} \times 100 \%}{n} \ldots \ldots \ldots . . .
$$

Keterangan :

$x_{i}=$ Nilai aktual pada periode .

$F_{i}=$ Nilai peramalan pada periode .

$\mathrm{n}$ = jumlah periode

Lebih lanjut, hasil perhitungan nilai MAPE yang didapatkan menunjukkan kemampuan dari teknik peramalan yang dilakukan. Semakin rendah nilai MAPE maka teknik peramalan yang dipilih akurat dan memiliki kemampuan yang baik dalam meramal. Tabel 2 merupakan perbandingan tingkat akurasi 
hasil peramalan berdasarkan nilai MAPE (Pramana, 2016).

Tabel 2. Hasil peramalan berdasarkan nilai MAPE

\begin{tabular}{ll}
\hline \multicolumn{1}{c}{ MAPE } & Hasil Peramalan \\
\hline$<10 \%$ & Sangat Baik \\
$10-20 \%$ & Baik \\
$20-50 \%$ & Layak/Cukup \\
$>50 \%$ & Buruk \\
\hline
\end{tabular}

\section{HASIL DAN PEMBAHASAN}

Pada bagian ini, akan diuraikan hasil pengujian metode fuzzy Tsukamoto yang diujikan pada data BBM yang ditunjukkan oleh tabel 1. Lebih lanjut, data BBM yang akan diprediksi adalah jumlah penerimaan BBM jenis premium untuk periode bulan Maret 2017. Dimana, untuk memperoleh jumlah estimasi penerimaan BBM pada bulan Maret 2017 didapatkan informasi stok terakhir pada bulan Februari 2017 sebanyak 13.181 liter dan jumlah penjualan BBM sebesar 289.422 liter dengan penerimaan sebesar 280.000 liter.

Setelah mengetahui informasi tersebut, langkah pertama yang harus dilakukan untuk menghitung estimasi penerimaan BBM pada periode berikutnya adalah menentukan nilai variabel input dan output. Dimana, nilai ini digunakan untuk membuat fungsi keanggotaan fuzzy variabel penjualan, persediaan (stok awal), dan penerimaan. Nilai variabel input dan output ditentukan berdasarkan nilai maksimum dan minimum yang terdapat pada data BBM. Adapun nilai input dan output yang digunakan dalam penelitian ini ditunjukkan oleh Tabel 3 .

Tabel 3. Nilai variabel input dan output

\begin{tabular}{cccc}
\hline $\begin{array}{c}\text { Nilai } \\
\text { Max/Min }\end{array}$ & $\begin{array}{c}\text { Variabel } \\
\text { Stok } \\
\text { Awal }\end{array}$ & $\begin{array}{c}\text { Variabel } \\
\text { Penjualan }\end{array}$ & $\begin{array}{c}\text { Variabel } \\
\text { Penerimaan }\end{array}$ \\
\hline $\begin{array}{c}\text { Nilai } \\
\text { Minimum } \\
\text { Nilai } \\
\text { Maksimal }\end{array}$ & 3.274 & 277.339 & 280.000 \\
\hline
\end{tabular}

Langkah selanjutnya adalah pendefinisan aturan dan variabel fuzzy yang dilakukan berdasarkan diskusi dengan pihak SPBU. Dari diskusi tersebut, diperoleh aturan fuzzy yang akan digunakan dapat dilihat pada Tabel 4 .

Tabel 4. Aturan fuzzy

\begin{tabular}{|c|c|c|c|}
\hline \multirow[t]{2}{*}{ Rule } & \multicolumn{2}{|c|}{ IF } & \multirow{2}{*}{$\begin{array}{c}\text { THEN } \\
\text { Penerimaan }\end{array}$} \\
\hline & Permintaan & Persediaan & \\
\hline R1 & Turun & Banyak & Berkurang \\
\hline $\mathrm{R} 2$ & Turun & Sedikit & Berkurang \\
\hline
\end{tabular}

\begin{tabular}{cccc}
\hline R3 & Naik & Banyak & Bertambah \\
R4 & Naik & Sedikit & Bertambah \\
\hline
\end{tabular}

Setelah menentukan aturan fuzzy, nilai minimum dan maksimal dari setiap variabel, langkah selanjutnya adalah melakukan proses fuzzyfikasi. Dalam proses fuzzyfikasi terdapat 4 (empat) variabel fuzzy yang akan dimodelkan, yaitu Stok Turun, Stok Naik, Penjualan Turun, dan Penjualan Naik. Dari setiap variabel tersebut dicari nilai keanggotaan menggunakan fungsi keanggotaan himpunan fuzzy dengan menggunakan persamaan 2,3,4,5. Nilai keanggotaan dari setiap variabel terdapat pada Tabel 5 .

Tabel 5. Nilai keanggotaan variabel fuzzy

\begin{tabular}{ll}
\hline Variabel & Nilai \\
\hline Stok Turun & 0,7438794 \\
Stok Naik & 0,2561206 \\
Penjualan Turun & 0,9481136 \\
Penjualan Naik & 0,0518864 \\
\hline
\end{tabular}

Selanjutnya, mencari nilai $\mathrm{Z}$ dari setiap aturan yang telah ditentukan. Nilai $\mathrm{Z}$ dari setiap aturan dicari dengan menggunakan persamaan 11 untuk aturan kesatu [R1], persamaan 14 untuk aturan kedua [R2], persamaan 17 untuk aturan ketiga [R3], dan persamaan 20 untuk aturan keempat [R4]. Nilai z dari setiap aturan dapat dilihat pada Tabel 6 .

Tabel 6. Nilai peramalan untuk setiap aturan

\begin{tabular}{lll}
\hline Aturan & $\begin{array}{l}\text { Hasil } \\
\text { peramalan }\end{array}$ & Nilai \\
\hline$[$ R1] & Z1 & 452.580 \\
{$[$ R2] } & Z2 & 339.420 \\
{$[$ R3] } & Z3 & 292.038 \\
{$[$ R4] } & Z4 & 292.038 \\
\hline
\end{tabular}

Setelah mendapatkan nilai $\mathrm{Z}$ dari setiap aturan, langkah berikutnya adalah mencari nilai tegas $\mathrm{Z}$ tiap ukuran dengan menggunakan rata - rata terbobot. Pada langkah ini untuk menghitung nilai $\mathrm{Z}$ dapat dihitung dengan menggunakan persamaan 21. Perhitungan nilai tegas $\mathrm{Z}$ adalah sebagai berikut.

$$
\begin{aligned}
& Z=\frac{(0.2561206 * 452580)+\cdots+(0.0518864 * 292038)}{(0.2561206+0.7438794+0.0518864+0.0518864)} \\
& Z=361.223
\end{aligned}
$$

Nilai Z yang didapatkan dari perhitungan diatas adalah 361.223. Dimana, nilai tersebut merupakan nilai yang menunjukkan hasil 
peramalan stok BBM pada periode berikutnya. Sehingga, pada bulan Maret 2017 diperkirakan penerimaan stok BBM yang seharusnya diterima oleh pihak SPBU dari pertamina berjumlah sekitar 361.223 liter.

\section{A. Implementasi Sistem}

Implementasi sistem menggambarkan tampilan dari sistem yang dibangun yaitu implementasi sistem estimasi stok bahan bakar. Tampilan halaman depan sistem ditunjukkan oleh Gambar 5.

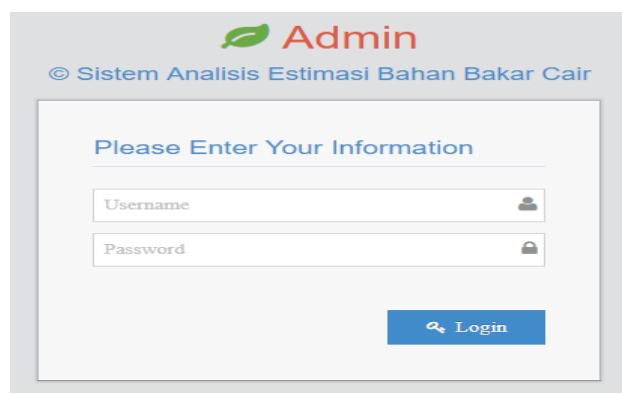

Gambar 5. Tampilan halaman depan sistem

Tampilan selanjutnya adalah tampilan halaman utama sistem. Halaman ini akan muncul setelah user melakukan login. Halaman ini berisi tampilan menu-menu yang terdapat pada sistem yang ditunjukkan oleh

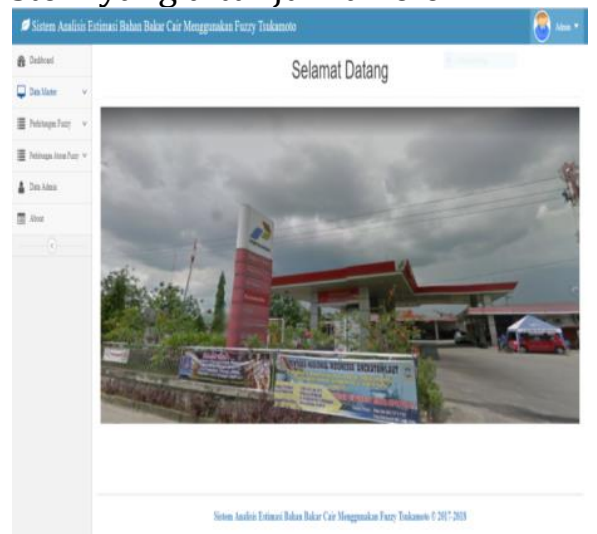

Gambar 6. Tampilan halaman utama sistem

Tampilan menu data master, berisi tampilan menu berbagai data jenis BBM. Tampilan data menu premium berisi informasi tentang jumlah stok, penjualan dan penerimaan BBM jenis premium berdasarkan periode tertentu. Gambar 7 menunjukkan tampilan data BBM jenis premium.

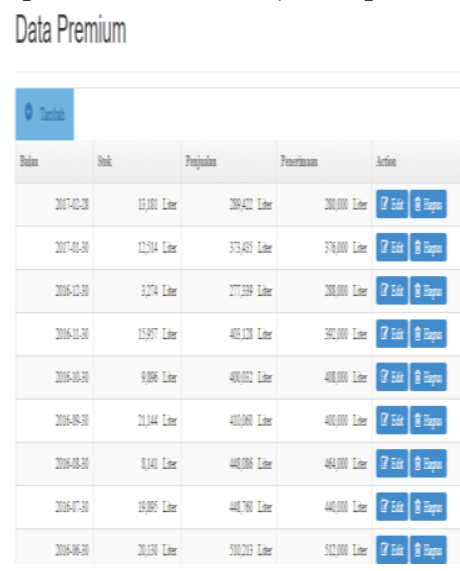

Gambar 7. Tampilan menu data premium

Pada menu perhitungan fuzzy berisi informasi yang menampilkan batasan - batasan variabel yang akan dihitung yaitu batasan jumlah stok minimum, maksimal, dan stok terakhir. Selain itu, terdapat batasan jumlah penjualan minimum, maksimal, dan penjualan terakhir. Serta, batasan jumlah penerimaan minimum, maksimal, dan jumlah penerimaan terakhir. Tampilan halaman perhitungan fuzzy dapat dilihat pada Gambar 8

\section{Form Perhitungan Estimasi Stok Premium

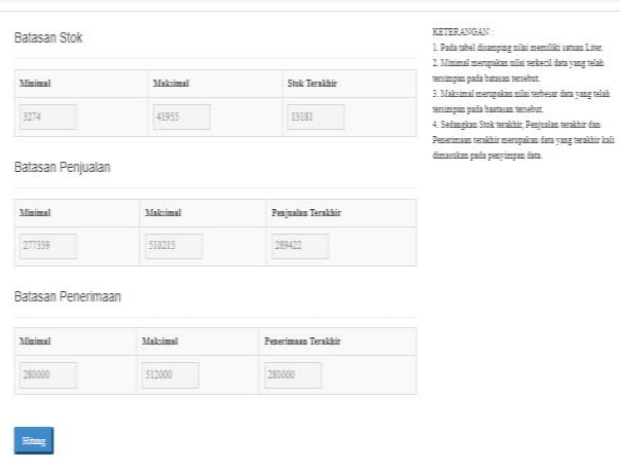 \\ Gambar 8. Tampilan menu perhitungan fuzzy}

Tampilan menu perhitungan aturan fuzzy menampilkan informasi aturan fuzzy yang dapat ditambah maupun diubah oleh user. Sistem memberikan batasan bahwa minimal terdapat satu aturan fuzzy yang harus diterapkan dalam sistem. Tampilan menu perhitungan aturan fuzzy ditunjukkan oleh Gambar 9. 


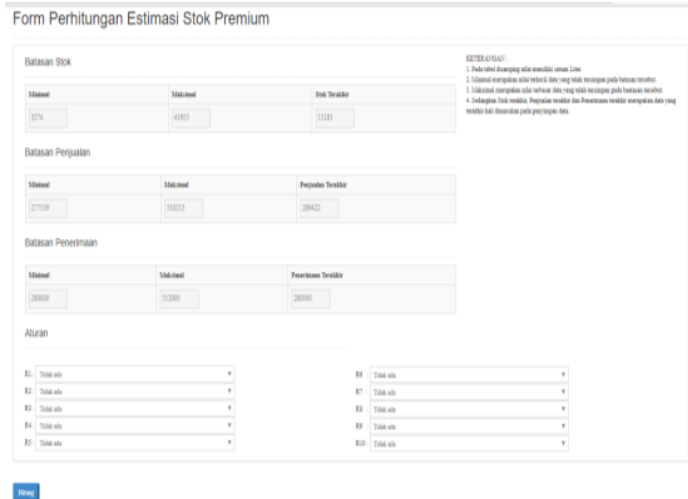

Gambar 9. Tampilan menu perhitungan fuzzy

Tampilan halaman detail perhitungan estimasi stok penerimaan BBM jenis premium berisi informasi tentang hasil perhitungan estimasi stok penerimaan BBM pada periode berikutnya. Dimana, pada halaman ini juga ditampilkan informasi nilai-nilai keanggotaan fuzzy dan hasil peramalan dari setiap aturan menurut aturan yang telah ditetapkan seperti terlihat pada Gambar 10.

Form Detail Perhitungan Estimasi Penerimaan Bahan Bakar Minyak

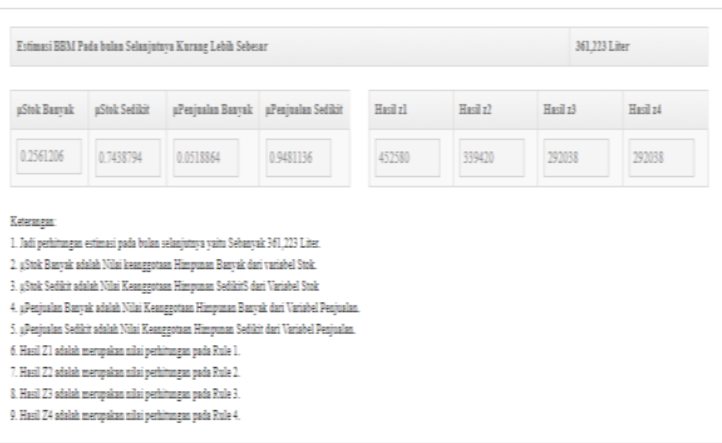

Gambar 10. Tampilan halaman detail perhitungan fuzzy

\section{B. Analisis Uji Validitas}

Analisis uji validitas hasil peramalan dilakukan untuk melihat selisih error antara hasil prediksi dengan data aktual. Selanjutnya, perhitungan pengujian validitas pada penelitian ini dilakukan dengan membandingkan hasil perhitungan yang dilakukan oleh sistem (data prediksi) dengan data nyata (real). Pengujian validitas dilakukan menggunakan metode MAPE (Mean Absolute Percentage Error). Pengujian menggunakan data BBM jenis premium pada bulan April 2016 sampai Februari
2017. Tabel pengujian validitas dapat dilihat pada Tabel 7.

Tabel 7. Pengujian validitas peramalan

\begin{tabular}{ccccc}
\hline $\mathbf{n}$ & $\begin{array}{c}\boldsymbol{x}_{\boldsymbol{i}} \text { (data } \\
\text { real) }\end{array}$ & $\begin{array}{c}\boldsymbol{F}_{\boldsymbol{i}} \text { (data } \\
\text { prediksi) }\end{array}$ & $\boldsymbol{x}_{\boldsymbol{i}}-\boldsymbol{F}_{\boldsymbol{i}}$ & $\begin{array}{l}{\left[\boldsymbol{x}_{\boldsymbol{i}}\right.} \\
\left.-\boldsymbol{F}_{\boldsymbol{i}}\right] \\
\boldsymbol{/} \boldsymbol{x}_{\boldsymbol{i}}\end{array}$ \\
\hline 1 & 480.000 & 456.000 & 24.000 & 0,05 \\
2 & 408.000 & 473.059 & 65.059 & 0,16 \\
3 & 464.000 & 408.000 & 56.000 & 0,12 \\
4 & 512.000 & 458.189 & 53.811 & 0,11 \\
5 & 440.000 & 488.540 & 48.540 & 0,11 \\
6 & 464.000 & 451.407 & 12.593 & 0,03 \\
7 & 400.000 & 448.654 & 48.654 & 0,12 \\
8 & 408.000 & 451.234 & 43.234 & 0,11 \\
9 & 392.000 & 411.023 & 19.023 & 0,05 \\
10 & 300.000 & 432.562 & 132.562 & 0,44 \\
11 & 376.000 & 300.000 & 76.000 & 0,20 \\
12 & 280.000 & 388.316 & 108.316 & 0.39 \\
& & & Jumlah & 1,880 \\
\hline
\end{tabular}

Berdasarkan data pada Tabel 7 maka persentase tingkat error sistem dengan menggunakan persamaan 22 adalah sebagai berikut.

$$
\begin{aligned}
\text { MAPE } & =\frac{(1,880) \times 100 \%}{12} \\
& =16 \%
\end{aligned}
$$

Berdasarkan hasil pengujian validitas yang telah dilakukan terhadap 12 data training, persentase error yang didapatkan adalah sebesar $16 \%$. Hal ini menunjukkan bahwa prediksi estimasi stok BBM jenis premium pada bulan Maret 2017 memiliki hasil peramalan yang baik berdasarkan kriteria hasil peramalan MAPE yang ditunjukkan oleh Tabel 2.

\section{KESIMPULAN}

Berdasarkan hasil pengujian dan analisis sistem estimasi stok penerimaan BBM, maka dapat disimpulkan bahwa sistem ini mampu memberikan rekomendasi dalam memutuskan jumlah penerimaan stok BBM yang diterima oleh pihak SPBU dengan menggunakan metode Fuzzy Tsukamoto sehingga keputusan yang diperoleh lebih tepat, terkomputerisasi dan mencegah pengambilan keputusan yang bersifat subjektif. Metode Fuzzy Tsukamoto mampu melakukan prediksi stok penerimaan BBM dikarenakan masalah yang dihadapi bersifat monoton dan hanya satu jenis persediaan yang dikelola saja. Selanjutnya dari analisis uji validitas hasil peramalan yang dilakukan, untuk melihat seberapa besar akurat hasil prediksi stok penerimaan BBM yang didapatkan menunjukkan bahwa metode Fuzzy Tsukamoto mampu memprediksi stok 
dengan baik. Dengan tingkat akurasi sistem sebesar 84\%. Hasil penelitian ini dapat menjadi rekomendasi bagi pihak SPBU untuk menentukan jumlah penerimaan stok BBM pada bulan berikutnya. Perbandingan metode fuzzy inference system, optimalisasi metode Fuzzy Tsukamoto menggunakan metode pengambilan keputusan seperti Simple Additive Weight, algoritma genetika merupakan rencana penelitian ke depan.

\section{DAFTAR PUSTAKA}

Ardianto, C., Haryanto, H., \& Mulyanto, E. (2018). Prediksi Tingkat Kerawanan Kebakaran di Daerah Kudus Menggunakan Fuzzy Tsukamoto. Creative Information Technology Journal, 4(3), 186-194.

Caraka, A. A., Haryanto, H., Kusumaningrum, D. P., \& Astuti, S. (2015). Logika Fuzzy Menggunakan Metode Tsukamoto untuk Prediksi Perilaku Konsumen di Toko Bangunan. Techno. Com, 14(4), 255-265.

Hayadi, B. H. (2015). SISTEM PERSEDIAAN KAYU JATI DENGAN FUZZY TSUKAMOTO. Komputer Teknologi Informasi, 2(2).

Huda, M. (2018). Model Prediksi Kebutuhan Bahan Baku Pada Cafe Menggunakan Algoritma Fuzzy Tsukamoto. Konferensi Nasional Sistem Informasi (KNSI) 2018.

Kusuma, A. P., Puspitasari, W. D., \& Gustiyoto, T. (2018). SISTEM PENDUKUNG KEPUTUSAN DALAM MENENTUKAN JUMLAH PRODUKSI SERAGAM MENGGUNAKAN METODE FUZZY TSUKAMOTO. ANTIVIRUS: Jurnal Ilmiah Teknik Informatika, 12(1).

Kusumadewi, S., \& Purnomo, H. (2004). Aplikasi Logika Fuzzy untuk pendukung keputusan. Yogyakarta: Graha Ilmu, 8.

Kusumaningrum, O., Suhartono, S., \& Haryono, H. (2012). Peramalan
Kebutuhan Bahan Bakar Premium di Depot Ampenan dengan Metode Hibrida Arima-Neural Network untuk Optimasi Persediaan. Jurnal Sains dan Seni ITS, 1(1), D194-D200.

Minarni, M., \& Aldyanto, F. (2016). Prediksi Jumlah Produksi Roti Menggunakan Metode Logika Fuzzy (Studi Kasus: Roti Malabar Bakery). Jurnal TeknoIf, 4(2).

Pramana, I. P. A. A. (2016). Peramalan Jumlah Kasus Demam Berdarah di Kabupaten Malang Menggunakan Metode Fuzzy Inference System. Jurnal Teknik ITS, 5(1).

Puryanto, T. (2016). Sistem Perencanaan Penambahan Stok Barang menggunakan Metode Fuzzy C-Means dan Fuzzy Tsukamoto (Studi Kasus di Distributor Alfamart Semarang). Jurnal Teknologi dan Sistem Informasi, 2(2), 43-52.

Santika, G. D., \& Mahmudy, W. F. (2015). Penentuan Pemasok Bahan Baku Menggunakan Fuzzy Inference System Tsukamoto. SESINDO 2015, 2015.

Sari, D. R. (2015). Aplikasi Penerapan Metode Neural Network Menggunakan Algoritma Backpropagation Untuk Mengetahui Pembelian dan Penjualan Bahan Bakar Industri. Infoteknik, 16(1), 47-60.

Setiadji. (2009). Himpunan dan Logika Samar serta Aplikasinya: Graha Ilmu, Yogyakarta.

Sinaga, H. D. E., \& Irawati, N. (2018). PERBANDINGAN DOUBLE MOVING AVERAGE DENGAN DOUBLE EXPONENTIAL SMOOTHING PADA PERAMALAN BAHAN MEDIS HABIS PAKAI. JURTEKSI, 4(2), 197-204.

Widayani, W., Kusrini, K., \& Al Fatta, H. (2015). Perancangan Sistem Pendukung Keputusan Penentuan Impor Bawang Merah. Creative Information Technology Journal, 2(3), 181-191. 